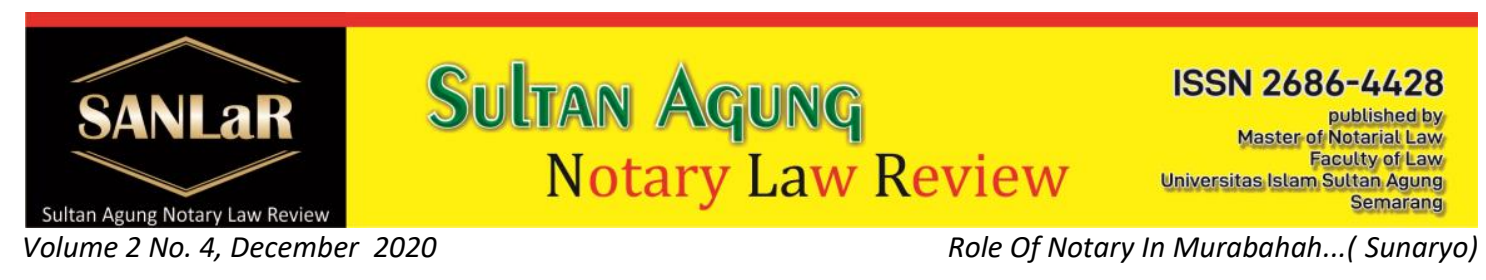

\title{
Role of Notary in Murabahah Transactions in Syariah Banks
}

\section{Sunaryo *)}

*) Student of Master of Notary Law, Faculty of Law, Universitas Islam Sultan Agung (UNISSULA) Semarang, E-mail: sunaryocipto5454@gmail.com

\begin{abstract}
The formulation of the problem in this research is how the role of the notary in implementation of the Murabahah financing contract in Sharia Banks and what are the obstacles to the role of a notary in completing a Murabahah financing contract at a Sharia Bank.The results of this study indicate that the notary has a different role when partnering Islamic banks. In his role, the notary is in charge of making Murabahah financing deeds at the sharia bank. Another role, the notary public also plays a role during dealings with people for the sake of whose notary deed was drawn up. In addition to people, there is also a place of position as the deed maker.
\end{abstract}

Keywords: Murabahah; Transactions; Syariah Banks.

\section{Introduction}

Notary is a public official appointed by the Government who has the authority to make authentic deeds. Thus the Notary has a very important role in efforts to create legal certainty and legal protection for the community. Legal certainty and protection is manifested in an authentic deed made by a notary as perfect evidence in court. It is said to be perfect evidence because authentic deeds contain three evidentiary powers, namely formal proof (formele bewijskracht), external proof (uitwendige bewijsracht) and material proving power (material bewijskracht) ${ }^{1}$

In Article 1867 of the Civil Code, it is stated that there is the term Authentic Deed, and Article 1868 of the Civil Code provides an elemental limitation what is meant by an Authentic Deed, namely²:

a. The deed must be drawn up by (door) or in the presence (ten overstaan) of a General Official.

b. The deed must be made in the form prescribed by law.

c. Public Employees (Public Officials) by or in front of whom the deed is made, must have the authority to make the deed.

\footnotetext{
${ }^{1}$ Adjie, Habib \& Hafidh, M. (2011). Akta Perbankan Syariah (Yang Selaras Pasal 38 UUJN). Semarang: Pustaka Zaman.

${ }^{2}$ Habib Adjie, (2011). Kebatalan Dan Pembatalan Akta Notaris. Bandung: PT Refika Aditama.
} 
The house is a basic human need as the main human need, so the house is in demand by many people, especially newlyweds. However, soaring house prices have made it rare for people to be able to buy a house with cash, so buying in installments or renting is the preferred alternative. There are many ways that people can take to meet their basic needs in terms of housing. This is where the Bank appears to bridge the interests of home buyers and sellers by offering KPR (Home Ownership Credit) facilities.

Sharia Bank is a bank that offers home ownership financing facilities that are applied with a Murabahah contract, and an istishna 'contract which are considered the most simple and efficient, this has made some people interested in using these financing facilities which have clearly avoided usury. One of the important elements for the implementation of Murabahah and isthisna 'financing by Bank Syariah Mandiri Semarang is the contract between the bank and the customer. In this case the contract is carried out based on Islamic law. This is what makes the authors choose Islamic Bank as a reference for further research related to the implementation of home ownership financing.

In providing home ownership financing facilities, it cannot be separated from the role of the Notary, because through the Bank's Notary and the customer, the agreement is made, so that it can be used as authentic evidence or perfect evidence, so that the parties making the agreement will be protected by legal certainty, however, the Notary in pouring out the agreement made by the tappers or the Notary Public is obliged to "act in a trustworthy, honest, independent, impartial, and safeguard the interests of the parties involved in legal actions". From the quotation of Article 16 paragraph (1) of the UUJN, it can be concluded that the Notary Public must be fair and impartial to either party, but the Notary must be neutral in pouring out the agreement made by the parties.

\section{Research Methods}

The method used in writing this journal is an empirical method. With the starting point of primary or basic data, namely data obtained directly from the community as the first source through field research conducted either through observation, interviews, or questionnaires. ${ }^{3}$. The specification of this research is descriptive analytical, which is research that aims to describe (describe) a problem in a certain area or at a certain time. Types and sources of data used in this paper consist of primary data and secondary data. Primary data is obtained directly from the first source in the field through research, namely from the behavior that exists in the community while secondary data includes official documents, books, research results in the form of reports, diaries and so on. ${ }^{4}$ Primary data in this study are the results of

\footnotetext{
3 Jonaedi, Efendi \& Ibrahim, J. (2016). Metode Penelitian Hukum Normatif dan Empiris. Jakarta: Kencana

${ }^{4}$ Soekanto, Soerjono \& Mamudji, S. (2001). Penelitian Hukum Normatif Suatu Tinjauan Singkat. Jakarta: Raja Grafindo
} 
direct observations at Bank Syariah Mandiri, direct interviews with employees and local notaries.

\section{Results and Discussion}

\subsection{The Role of Notaries in Making Implementation Murabahah Contract for Financing in Sharia Banks}

Notaries play a very important role in making deeds related to financing home ownership, not only making deeds, the role of the Notary also legalizing agreements made by banks and customers, Notary's authority, according to Article 15 UUJN is to make Authentic Deeds regarding deeds, agreements and provisions who are required by laws and regulations and/or those interested in being stated in the Authentic Deed, guarantee the certainty of the making of the Deed, keep the Deed, provide grosse, copy and excerpt of the Deed, all of which as long as the making of the Deeds is not assigned excluded from other officials or other people determined by law.

Notary, apart from having the authority to make an authentic deed both by him and in front of him, which is his main daily duty, the notary can also take the following actions:

a. Acting as a legal advisor, especially those concerning civil law issues in a broad sense (privaat);

b. Registering (waarmerking) on deeds or under-handed documents and documents (stukken).

c. Legalize signatures;

d. Creating and ratifying (waarmerking) copies or derivatives of various documents (copy collationee)

e. Seek to legalize bodies such as Limited Liability Companies/Foundations to obtain approval/ratification as legal entities and the Minister of Justice and Human Rights;

Cooperation between a notary and a sharia bank in making a deed of financing with sharia principles, then the financing that is usually handled by a notary in principle consists of:

a. Musyarakah financing, namely financing between 2 (two) parties to carry out a certain business and from that business the profits will be shared according to the agreement.

b. Mudharabah financing, which is financing in which one party is the manager while the other party is the provider of capital. Meanwhile, the refund of the principal is adjusted to the cash flow or business cash flow of the customer so that it will not burden the customer

c. Financing on the principle of ijarah or lease

d. Murabaha Financing

In this assignment, lies the giving of a sign of trust to these officials and the granting of evidentiary power to the deeds they make which legally have three powers of proof, namely:

a. Strength of Evidence Outward/Outside;

b. The Power of Formal Evidence; 


\section{c. Proof of Material Strength;}

Therefore, based on the results of an interview with a notary in Banyumas, the role of the notary in making a financing agreement deed in a sharia bank is that in terms of financing, it always requires an agreement that contains a complete clause to ensure legal certainty in order to minimize risk by the Islamic bank. In formal juridical terms, there are 2 (two) types of contracts made by Islamic banks, namely:

a. Sharia financing contract under hand or deed under hand and

b. Sharia financing agreement made by and in front of a notary (notary) or an authentic deed.

From this explanation, the authority of the Notary is very broad regarding the making of an Authentic Deed as long as it is not excluded from other officials stipulated by law. In carrying out its duties, the Notary legalizes the Murabahah contract and the wakalah contract made by the Bank with the customer, and legalizes the istishna 'contract made by the Bank and the developer, and the Bank with the customer followed by the wakalah contract.

In carrying out its duties, the Notary must be guided by the UUJN and the Notary's Otik Code, if it is not guided or violates these regulations, of course the impact can be fatal, because the deed can be degenerated into a deed under the hand of the fiber of the deed can be canceled and null and void by law A Notary Deed that has under-hand evidentiary power is explicitly stated in certain articles in UUJN which state that if a notary violates the deed, the deed has under-hand evidentiary power, as in Article 16 paragraph (1) letter i, namely not reading the deed in before an audience in the presence of at least 2 witnesses and signed at the same time by the audience, witnesses and a notary ", Article 16 paragraph (7) and paragraph (8).

\subsection{Barriers to the Role of Notary Public in Settlement of Murabahah Financing Contracts in Sharia Banks}

In the implementation of home ownership financing, of course there are obstacles experienced by several related parties, therefore these obstacles are expected to be resolved in the future by the parties concerned, both from the Bank, Developer, Notary, and customers. The obstacles experienced in implementing home ownership financing are as follows.

From the bank, the problem is that there are still many customers who do not know and understand well the principles of sharia, many customers are not able to distinguish what is a buying and selling contract, namely Murabahah, istisna, salam with profit sharing contracts, namely mudharabah, musyarakah, or with a contract. lease namely ijaroh. Whereas in principle, there are differences in principle between the three types of funding/financing contracts that can be applied to Islamic banks. Therefore it is necessary to hold outreach to the public so that people understand what is meant by the sharia contract, as well as what contracts are appropriate and can be applied in financing.

The obstacle experienced by the Notary is in making the deed, especially at the time of reading and signing the deed, because if one of the parties is not present, the reading and signing of the deed will be postponed, but in reality the Notary will still sign the deed. This certainly violates the existing regulations, but on the other hand the parties 
have entrusted the Notary because they have become partners to take care of the deed, and not all parties know that the consequences of not fulfilling this can become an underhand agreement whose power of proof is in under the hand.

The constraints experienced by the Developer are regarding the solving of the master certificate at the City or Regency level National Land Agency which takes a long process, to respond to this the parties take the road through an accelerated process, for the process at BPN is not only for solving certificates but all a process involving BPN. This seems to be a culture or a habit for BPN to undertake or take the road through an accelerated process. In this case, the writer argues that BPN should not do this, because BPN has the duty to serve the community in matters related to land, I hope that in the future the Government will supervise BPN both at the City or Regency level.

\section{Closing}

The role of the notary in making deeds related to home ownership financing, namely legalizing the contract or agreement and making an authentic deed, in practice at the Sharia Notary Bank legalizes the Murabahah contract which is followed by the wakalah contract, and the istishna 'contract followed by the wakalah agreement, and the Notary makes the Deed recognition of financing as an affirmation of home ownership financing. The other side of this notary practice plays a role in legalizing the sharia contract in the form of the Murabahah contract followed by the wakalah contract, the istishna 'contract followed by the wakalah contract, and the mutanaqisah musyarakah contract. In addition to legalizing Notaries, they also make PPJB Deeds between customers or consumers and developers, buy back guarentee deeds as a form of developer guarantee against the Bank if the customer experiences defaults in payment, and make SKMHT from customer to Bank. In carrying out its duties, a Notary must carry out the obligations of a Notary which are contained in the UUJN or the Notary's Code of Ethics. If the Notary violates Article 16 paragraph (1) letter i UUJN, namely reading the contents of the deed followed by the signing of the deed, then the result is that the deed has the power of proof reduced to a deed under hand and if the Notary violates this article, the Notary automatically also violates Article 16 paragraph (1) letter a, which requires acting trustworthy, honesty and impartiality.

\section{References}

Books:

[1] Adjie, Habib \& Hafidh, M. (2011). Akta Perbankan Syariah (Yang Selaras Pasal 38 UUJN). Semarang: Pustaka Zaman.

[2] Anshori, Abdul Ghofur, (2009). Lembaga Kenotariatan Indonesia Prespektif Hukum Dan Etika, UII Press, Yogyakarta.

[3] Jonaedi, Efendi \& Ibrahim, J. (2016). Metode Penelitian Hukum Normatif dan Empiris. Jakarta: Kencana 
[4] M. Syamsudin, (2007). Operasionalisasi Penelitian Hukum, PT Rajarafindo Persada, Jakarta.

[5] Soekanto, Soerjono \& Mamudji, S. (2001). Penelitian Hukum Normatif Suatu Tinjauan Singkat. Jakarta: Raja Grafindo

Regulation:

Act No. 2 of 2014 concerning Notary Position. 